\title{
Apple Pomace Microbiome Carrying Fungal Load against Phytopathogens - Considerations Regarding Application in Agriculture and Horticulture
}

\author{
Karolina Oszust,* and Magdalena Frąc \\ This experiment evaluated the taxonomic diversity of the fungal \\ community in conventional (AP) and organic (OAP) apple pomace using \\ high-throughput sequencing, applying fungal genetic barcodes to \\ functional guilds. The most abundant taxonomic groups identified in both \\ AP and OAP were the genera Aureobasidium, Cladosporium, and \\ Alternaria, classified into the pathotroph-saprotroph-symbiotroph guild. \\ The phenotype microarray provided insight into the role of the apple \\ pomace fungal community in the ecosystem. It is theorized that adding \\ apple pomace to the soil may improve the bioavailability of bioresource- \\ based polyols. Evaluation of the antagonistic ability of the AP fungal \\ community and Trichoderma atroviride G79/11 strain against pathogenic \\ fungi was performed. Trichoderma G79/11 developed well on apple \\ pomace and revealed the antagonistic mode against tested fungal plant \\ pathogens. Therefore, it could be applied to soil as a formulation of AP \\ with spores or AP with metaferm biopreparation.
}

Keywords: Apple waste; Fungal diversity; Phytopathogens; Antagonism; Trichoderma atroviride; Agriculture

Contact information: Institute of Agrophysics, Polish Academy of Sciences, Doświadczalna 4, 20-290 Lublin, Poland; *Corresponding author: k.oszust@ipan.lublin.pl

\section{INTRODUCTION}

A wide array of scientific activities and their resulting products, including biofertilizers, microbial pesticides, and bio-control agents, used to fight plant pathogens are present at the interface of applied microbiology and horticulture (Ray and Ward 2008). The use of advanced microbiological techniques and tools to characterize the genetic and functional diversity of the microbial community has also been recently proposed as a strategy in biowaste eco-toxicological evaluation (Oszust and Frąc 2018; Oszust et al. 2018a).

Of large-scale horticultural waste, the apple juice industry generates a large amount. The waste takes the form of apple pomace, the by-product that results from apple processing and consists of apple skin, seeds, and stems (Wang et al. 2019). Approximately $75 \%$ of apple fruit is processed for juice or cider, and the remaining $25 \%$ of the weight of the fresh fruit constitutes biowaste. Apples (Malus domestica) are the favoured fruit of millions of people, and are widely grown in the intemperate regions of the globe (Shalini and Gupta 2010). Poland is one of the major apple producers, with approximately $3170 \mathrm{Gg}$ of apples produced every year (Lipiński et al. 2018).

Fruit pomace is a generally rich source of biological compounds and has become an important raw material from which to obtain various valuable by-products. Thus, it offers a logical basis for waste management and apple pomace is used for fuel and food 
purposes, biotransformation, a source of fibre and pectin, microcrystalline cellulose (Shalini and Gupta 2010), nanocellulose (Szymańska-Chargot et al. 2019), and other bioactive compounds, such as organic acids and flavonoids (Mourtzinos and Goula 2019). Apple pomace application for agricultural purposes could be especially important for local apple processing companies surrounded by orchards and crops, which often lack sources of exogenous organic matter. The EU Thematic Strategy on Soil Protection lists the decline in organic matter as one of the main threats to soil quality, and calls for cultivation and agricultural production systems that will lead to an increase in its content (Soil Quality and Policy 2018).

The agricultural use of fruit pomace as a natural fertilizer promoting plant growth in organic farming has been studied previously (Mercy et al. 2014). Pomegranate, orange, sweet lime, and banana pomaces have promoted the growth of plants and have helped achieve higher yields, due to the organic matter and nutrients introduced. The risks and opportunities of organic farming have recently been summarized (Röös et al. 2018). It should be emphasized that additional fungal species may follow in the wake of biofertilizer application and may be unincorporated into the soil with almost any kind of biofertilizer (Frac et al. 2014).

Various microbial inhabitants may be described as indigenous representatives of biowaste. They may undertake a pivotal ecological role in influencing plant health as symbionts or decomposers when they are introduced to fields in the form of biofertilizers (Oszust et al. 2018a). In contrast, they may be pathogenic to plants, produce toxins, or cause mycoses (Presterl et al. 2018). To date, the mycological compositions of biofertilizers have been poorly analysed and described compared with analysis of their physicochemical properties (Oszust et al. 2018b).

However, biofertilizers may influence soil fungal biodiversity after their agricultural application. Therefore, the aims of the present study are as follows: [i] to assess the potential threats and benefits of introducing fungal representatives into the soil with apple pomace as a fertilizer, attributing fungal genetic barcodes to functional guilds, and thus evaluating the taxonomic diversity using high-throughput sequencing; and [ii] to provide insight into the role of fungal community maintenance in apple pomace ecosystem functionality. Herein, the specific respiration rate demonstrates a metabolic effect, in addition to biomass presented as a ratio development in the phenotype microarray. The methods of Pinzari et al. (2016) were followed and applied to the fungal community for the first time.

The statement that apple pomace carries a fungal load may also be considered from another point of view: namely, that waste is also a carrier of microbial beneficial strains, which are intended to be incorporated into the soil to fulfil a positive function. In that case, the indigenous microbial fungal species of the organic waste may be introduced into plant cultivation. Accordingly, it was discovered that fruit pomace, which is a solid waste, may be used as a growth substrate for microorganisms that inhibit plant pathogen development (Kalidas 1999).

The Trichoderma genus, a well-known fungus, is able to parasitize a great number of other soil-borne fungi that are pathogenic to plants. Trichoderma sp. comprises numerous biopreparations. Among others, Trichoderma atroviride G79/11 was previously described as a strain with cellulolytic potential (Oszust et al. 2017b), and based on the strain culture metaferm, a multi-enzymatic biopreparation was developed (Oszust et al. 2017a). However, no analysis has been performed to determine its antagonistic ability. 
It was assumed that Trichoderma atroviride G79/11, which revealed a relatively high cellulolytic activity, would also develop well on apple pomace and demonstrate an antagonistic activity against pathogens. Therefore, the third aim of this study is to [iii] evaluate the associated antagonism between apple pomace and the G79/11 strain against four fungal pathogens that have been known to devastate soft fruit plantations.

These pathogens were Colletotrichum sp., Botrytis sp., Verticillium sp., and Phytophthora sp. Colletotrichum sp. is a burdensome fungal pathogen in modern agriculture. C. acutatum is one of the most harmful species of this genus; it causes anthracnose in plants such as strawberries and raspberries (Dolan et al. 2018; Forcelini et al. 2018). Botrytis cinerea is a causal agent of grey mould, and its resistance to fungicide renders it one of the most harmful pathogens affecting raspberry and strawberry plants as it diminishes otherwise effective management strategies (Kozhar and Peever 2019; Weber and Hahn 2019). The Verticillium genus includes two major species, V. dahliae and $V$. alboatrum, that cause losses in agriculture. $V$. dahliae causes wilt on economically important crops including strawberries and raspberries (Fan et al. 2018). It is also theorized that the Phytophthora species is responsible for most strawberry and raspberry losses in all production areas of the world (Nellist 2018). Scientists distinguish between two varieties of this species: $P$. fragariae var. fragariae, which can only infect strawberries, and $P$. fragariae var. rubi, which is native to raspberries. The co-occurrence of those pathogens may appear, e.g., Phytophthora rubi and Verticillium dahliae in the form of late-summer disease symptoms in red raspberry fields (Weiland et al. 2017; Nellist et al. 2018). A universal natural enemy of those fungi is thus required in organic horticulture, especially because the worldwide area of organic cultivation has increased meaningfully over recent years (Kiełbasa 2015).

\section{EXPERIMENTAL}

\section{Materials}

Apple pomace

Two types of apple waste were used for the experiments: apple pomace (AP), a waste consisting of a mixture of red-coloured apple varieties grown conventionally in the Grójec area of Poland, obtained from a local apple juice-processing factory; and organic apple pomace (OAP) of the Gala variety that was ecologically grown in Trentino-Alto Adige, Italy. The content of mineral ingredients (NPK) and the organic matter content were evaluated. The phosphorus (P) level was calorimetrically determined and the potassium (K) content was estimated by flame photometry according to the Spurway method (Spurway and Lawton 1949). The total nitrogen and organic matter contents were assessed according to the Kjeldahl and weight method, respectively. All analyses were determined at the District Chemical and Agricultural Station in Rzeszów, Poland. The results were obtained in the form of mean values. All chemical analyses of the tested waste were performed in triplicate.

\section{Methods}

Next generation sequencing - Meta-barcoding

An analysis of the fungal community structure of apple pomace was performed on the basis of the region of Internal Transcribed Spacers 1 (ITS1). The set of the following primers ITS1FI2: 5'-GAACCWGCGGARGGATCA-3' (Schmidt et al. 2013) and 5.8S: 
5'-CGCTGCGTTCTTCATCG-3' (Vilgalys 1992) were used to amplify the selected region. The polymerase chain reaction (PCR) was completed in a Q5 Hot Start HighFidelity 2X Master Mix (New England Biolabs, Ipswich, MA, USA) according to the conditions included in the manufacturer's protocols. The DNA library was sequenced using an MiSeq platform (Illumina Inc., San Diego, CA, USA) with pair-end (PE) technology, 2 $\mathrm{x} 250 \mathrm{bp}$ using the v2 Illumina kit following the manufacturers' instructions (Genomed S.A., Warsaw, Poland). MiSeq Reporter (MSR) v2.6. software (Illumina Inc., San Diego, CA, USA) was used for a preliminary elaboration of the data and the Quantitative Insights into Microbial Ecology (QIIME) tool (Illumina Inc., San Diego, CA, USA) was used to process the raw sequencing data (Caporaso et al. 2010). The analysis included the following steps: reading quality evaluation, removing low quality sequences and chimeras, and generating operational taxonomic units (OTUs) that were defined by clustering at $97 \%$ similarity. The taxonomical classification of the OTUs was achieved using a Basic Local Alignment Search (BLAST) against the UNITE database.

A bioinformatics assay was based on the reference sequence database, Greengenes_13_05 (DeSantis, Jr. et al. 2006b), and was performed using an algorithm from Qiime software (Caporaso et al. 2010). The analysis included the following steps: demultiplexing of samples and adaptor cutting, conducting quality analysis, determining taxonomic composition, and performing diversity analysis. Sequences that were over $97 \%$ identical were grouped into one OTU using a distance-based OTU program. The application of MiSeq Reporter v2.3 (Illumina Inc., San Diego, CA, USA) allowed for species-level classifications. The taxonomy database for the metagenomics workflow was the Illumina version of the Greengenes database (DeSantis, Jr. et al. 2006a). FUNGuild was used to taxonomically parse fungal OTUs using the ecological guild (Nguyen et al. 2016).

\section{Phenotype microarray}

Phenotype fingerprinting of apple pomace (AP and OAP) fungal community was determined using the Biolog ${ }^{\circledR}$ System FF MicroPlates (Biolog®, Hayward, CA, USA), expressed as the ratio between the values of substrate use (respiration, OD $490 \mathrm{~nm}$ ) and the growth pattern (biomass production, OD $750 \mathrm{~nm}$ ); seven carbon source groups were evaluated (Pinzari et al. 2016, 2017). The protocol followed that of Jeszka-Skowron et al. (2018). The analyses were performed in tree technical replications $(n=3)$. Results are presented as mean values, and standard errors are provided.

\section{Microbial Strains and metaferm Biopreparation}

The following fungal pathogens were used in the study: two strains of Colletotrichum sp. (G166/18 and G168/18) isolated from infected strawberry fruit, two strains of Botrytis sp. (G277/18 and G276/18), two strains of Verticillium sp. (G296/18 and G297/18) isolated from infected strawberry roots, and two strains of Phytophthora sp. (G373/18 and G368/18) from the collection of the Research Institute of Horticulture in Skierniewice (Sierniewice, Poland). Concerning the beneficial and possibly antagonistic strain of Trichoderma atroviride G79/11, its origin and characteristics were described by Oszust et al. (2017b). Metaferm is a multi-enzymatic biopreparation previously developed and described by Oszust et al. (2017a). It reveals hydrolytic activities such as those involving: xylanase, $\beta$-glucosidase, carboxymethyl cellulase, poligalactouronase, pectinesterase, amylase, lactase, and protease (Frąc et al. 2014; Oszust et al. 2017a). The metaferm used for the purposes of the experiment was stored at $-20{ }^{\circ} \mathrm{C}$ for 4 years. 


\section{Antagonism Experiment}

To evaluate the interactions between the antagonistic variants and the pathogens in the in vitro culture, the following antagonistic variants were used: (1) Trichoderma atroviride (G79/11) (5-mm fragments of potato dextrose agar (PDA) cultured for 10 days), (2) AP (0.2 g), (3) AP inoculated with Trichoderma atroviride (AP-G79/11) (0.2 g AP inoculated via an inoculation needle with spores of G79/11), (4) metaferm (MET) $(100 \mu \mathrm{L}$ into the 5-mm diameter hole in PDA), and (5) AP with metaferm (AP-MET) (0.2 g AP and $100 \mu \mathrm{L}$ MET). They were tested against four selected pathogenic species (Colletotrichum sp., Botrytis sp., Verticillium sp., and Phytophthora sp.) represented by two isolates each.

The discs of 5-mm diameter PDA (with antibiotics addition) containing 10-day-old cultures of pathogenic fungi were placed on a Petri dish with $20 \mathrm{~cm}^{3}$ of PDA. The scheme of the antagonism experiment is shown in Fig. 1. Controls of all of the pathogenic strains without any treatment were provided. After incubating the pathogenic fungus and antagonism variant at $22{ }^{\circ} \mathrm{C}$ for approximately 5 days, the horizontal culture and vertical growth diameter $(\mathrm{mm})$ were measured. The experiment was set up in triplicates $(\mathrm{n}=3)$. Results were presented as mean values with standard error provided.

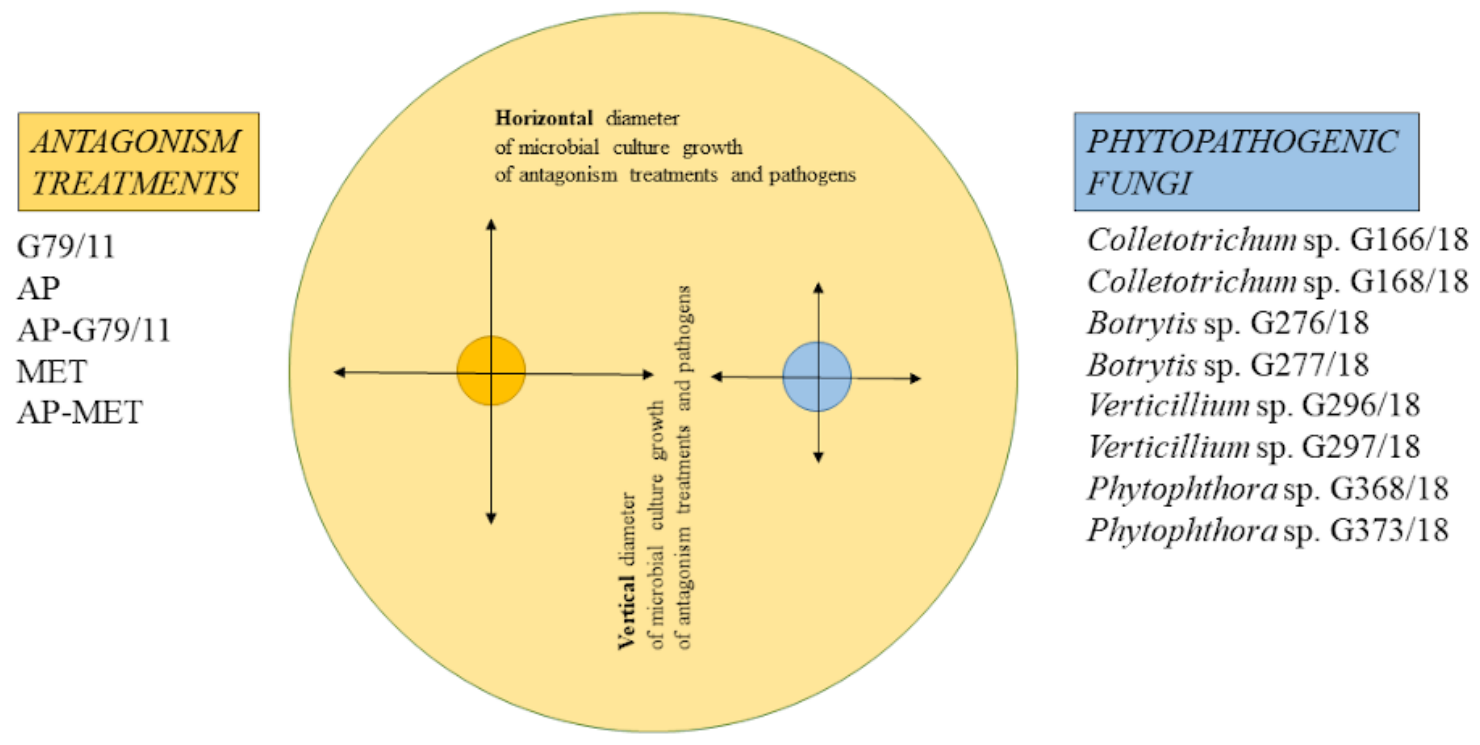

Fig. 1. Antagonism experiment diagram (explanations: G79/11 - Trichoderma atroviride G79/11; AP - apple pomace; AP-G79/11 - apple pomace inoculated with Trichoderma atroviride G79/11; MET - metaferm multi-enzymatic biopreparation based on post-culture, concentrated liquid of Trichoderma atroviride G79/11 in soy flour-cellulose-lactose medium; AP-MET - apple pomace with the addition of metaferm; $\mathrm{n}=3$ )

\section{RESULTS AND DISCUSSION}

Apple pomace and OAP exhibited differences with regards to their chemical properties, as shown in Table 1. The latter contained twice as much total nitrogen and phosphorus ( $1.18 \%$ and $0.14 \%$, respectively) as AP. Organic matter and potassium content were relatively equal in AP and OAP (0.8\% and 98\%, respectively). 
Table 1. Chemical Properties of Apple Pomace

\begin{tabular}{|c|c|c|c|c|c|}
\hline $\begin{array}{c}\text { Apple } \\
\text { Pomace }\end{array}$ & $\begin{array}{c}\text { Dry } \\
\text { Matter }\end{array}$ & $\begin{array}{c}\text { Total } \\
\text { Nitrogen } \\
(\mathrm{ON})\end{array}$ & $\begin{array}{c}\text { Phosphorus } \\
(\mathrm{P})\end{array}$ & $\begin{array}{c}\text { Potassium } \\
(\mathrm{K})\end{array}$ & $\begin{array}{c}\text { Organic } \\
\text { Matter (OM) }\end{array}$ \\
\cline { 2 - 6 } & \multicolumn{5}{|c|}{$\%$} \\
\hline $\mathrm{AP}^{*}$ & 26 & 0.496 & 0.085 & 0.81 & 98.04 \\
\hline OAP $^{* *}$ & 23 & 1.184 & 0.140 & 0.70 & 97.93 \\
\hline
\end{tabular}

The study evaluated the share of fungal OTUs in apple pomace organized into groups that referred to trophic modes (Fig. 2). Among all of the obtained OTUs for AP, $20 \%$ were assigned and organized into trophic modes. For OAP, the total assignment was $26 \%$. Therefore, $74 \%$ to $80 \%$ of the OTUs found were unassigned. In detail, the most numerous group of AP (constituting 18\% of all OTUs) and of OAP (constituting $23 \%$ of all OTUs) was assigned to the pathotroph-saprotroph-symbiotroph group. The pathotrophsaprotroph group was the second organized entry detected, but much less numerous (1\% in AP and $3 \%$ in OAP).

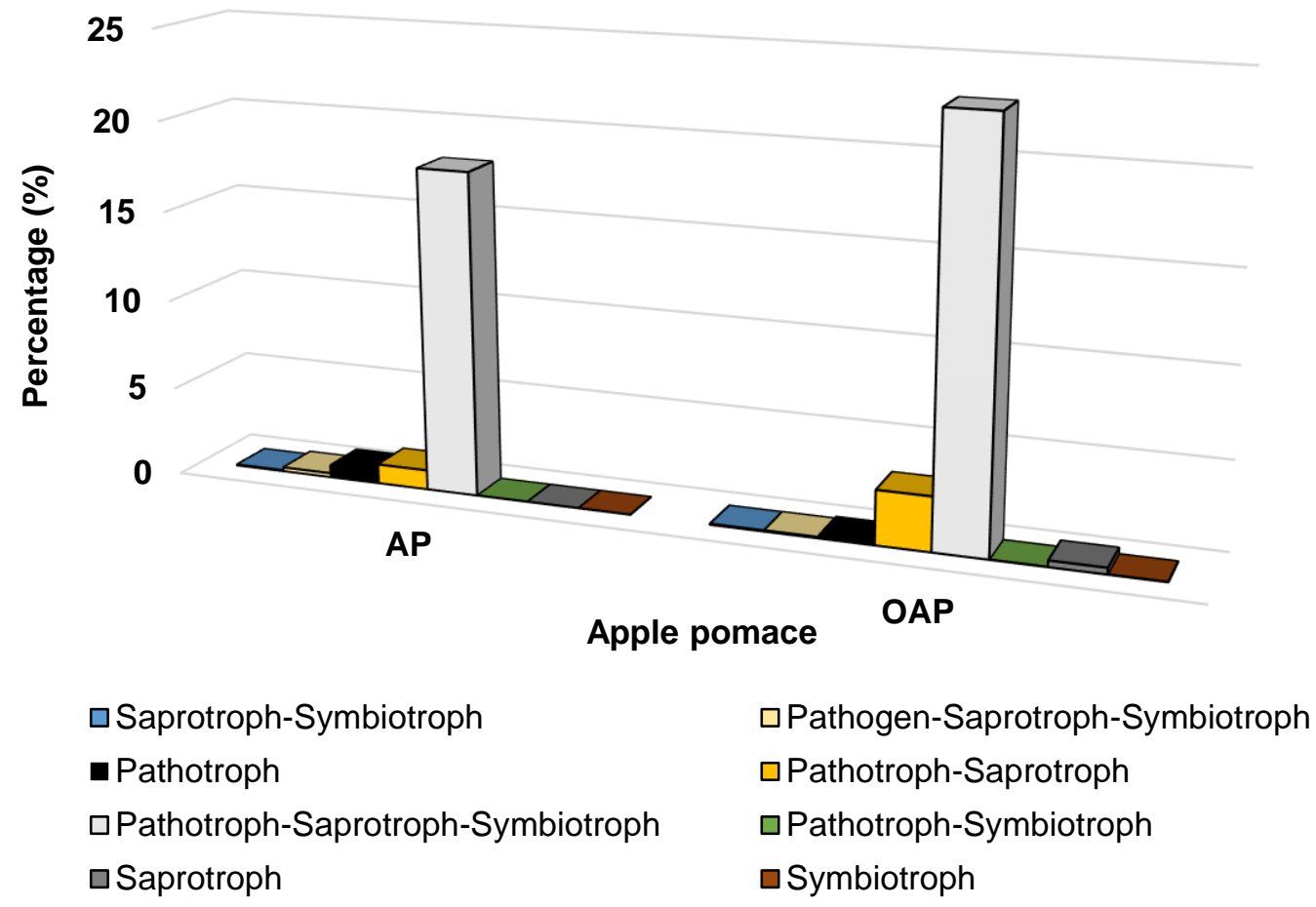

Fig. 2. The share of fungal OTUs entries organized into groups that referred to trophic modes in apple pomace

The relative abundance (\%) of fungal OTUs ID entries have been qualified directly into taxa and indicated with trophic modes and guilds, as shown in Table 2. Both yeasts and moulds were found, including soft rot, endophyte pathogens, fungal parasites, likely 
opportunistic human pathogens, biotrophic, necrotrophic, or saprobic, on various plant tissues or/and necrotrophic on stems or leaves.

The most abundant taxonomic groups at the genus level that were identified in both AP and OAP were Aureobasidium sp. (2.75\% and $12.7 \%$, respectively), Cladosporium sp. (4.16\% and $7.31 \%$, respectively), and Alternaria sp. (0.93\% in AP and $2.56 \%$ in OAP) were classified into pathotroph-saprotroph-symbiotroph group. Malassezia sp. representatives (0.1\% in AP and $0.05 \%$ in OAP) and Leptosphaeria sp. were also found in both AP and OAP, though in a smaller amount $(0.5 \%$ and $0.07 \%$, respectively). The following genera: Phoma, Acremonium, Mycosphaerellaceae, and Exobasidium primarily occurred in AP. The genera Leptosphaeriaceae, Didymella, Sporobolomyces, and Rhodotorula were only found in OAP.

Among all the taxa described, only Malassezia sp. $(<0.1 \%$ in AP and OAP) and Sporobolomyces sp. (0.2\% in OAP) were not thought to behave as plant pathogens. The animal pathogens in both AP and OAP were Cladosporium sp., Alternaria sp., and Malassezia sp.; in AP, Acremonium sp.; and, in OAP, Didymella sp. and Rhodotorula sp. Most of entries were classified as probable saprotrophs. Only two representatives were assigned to perform fungal parasitism, Acremonium sp. (0.15\% AP) and Sporobolomyces sp. $(0.2 \%$ OAP).

An evaluation of in vitro antagonism treatments on PDA against Colletotrichum sp. isolates is shown with photographic documentation in Fig. 3 (a to d), Botrytis sp. in Fig. 4 (a to d), Verticillium sp. in Fig. 5 (a to d), and Phytophthora sp. in Fig. 6 (a to d). Botrytis sp. and Colletotrichum sp. were the most expansive in this experiment. Botrytis sp. isolates outgrew the petri plate (diameter $80 \mathrm{~mm}$ ), which meant that it was the most expansive sample among the pathogens tested. Colletotrichum sp. growth was slightly lower $(60 \mathrm{~mm})$. The slightest growth was noted for the Verticillium sp. $(<40 \mathrm{~mm})$ and Phytophthora sp. isolates $(<12 \mathrm{~mm})$.

Almost all proposed antagonism treatments were effective for pathogenic fungi growth inhibition, which was demonstrated by the decrease in horizontal and vertical growth diameter. Colletotrichum sp. isolates had an approximately $70 \%$ diameter decrease in G79/11 and AP-G79/11 strains, and 30\% for AP, MET, and AP-MET. For Botrytis sp. G279/18, a 50\% decrease was noted for AP, G79/11, and AP-G79/11, and 25\% for MET and AP-MET. For Botrytis sp. G277/18, a 50\% decrease was observed for G79/11, APG79/11, AP-MET, and a 25 to 30\% decrease for AP and MET. In contrast, for Verticillium sp. G269/18 and G297/18, a 50\% decrease for AP, and 70\% decrease was noted for the rest of tested treatments. The only exception was Phytophthora sp. G373/18, which was not influenced by antagonists. The isolate Phytophthora sp. G368/18 was revealed to be immune.

The inhibition effect differed with respect to the particular treatment. Generally, AP treatment revealed the lowest inhibition activity. However, the direct addition of Trichoderma atroviride G79/11 to AP in the form of spores (AP-G79/11), or indirectly with metaferm (AP-MET), predominantly improved the efficacy of its antagonistic activity. This improvement was manifested by the overgrowth of G79/11. For Colletotrichum sp. G166/18 (Fig. 3c) and Verticillium sp. G269/18 (Fig. 5c), no G79/11 development was noted in the AP-MET treatment, and other fungi exceeded its growth. As shown in various photos (Figs. 3c, 3d, 4c, 4d, 5c, 5d, 6c, and 6d), for AP treatment, macroscopic evaluation showed that AP treatment favoured development of different species, demonstrating a probable antagonistic treatment. 
Table 2. Relative Abundance (\%) of Fungal OTUs with Trophic Modes and Guilds Identified

\begin{tabular}{|c|c|c|c|c|c|c|c|c|}
\hline \multirow{2}{*}{ OTU ID } & \multirow{2}{*}{$\begin{array}{l}\text { Trophic } \\
\text { Mode }\end{array}$} & AP & OAP & \multirow{2}{*}{ Taxon } & \multirow{2}{*}{ Guild } & \multirow{2}{*}{$\begin{array}{l}\text { Growth } \\
\text { Morphology }\end{array}$} & \multirow{2}{*}{ Notes } & \multirow{2}{*}{ Citation/Source } \\
\hline & & \multicolumn{2}{|c|}{$\%$} & & & & & \\
\hline $\begin{array}{l}\text { New.Reference } \\
\text { OTU17 }\end{array}$ & \multirow{6}{*}{ 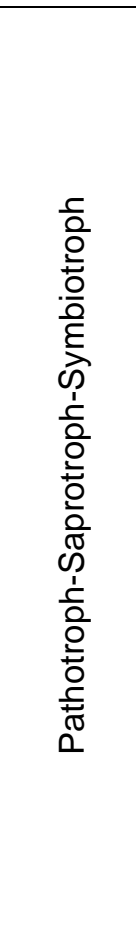 } & 8.74 & 0.06 & Phoma & $\begin{array}{l}\text { Endophyte-Dung Saprotroph- } \\
\text { Lichen Parasite-Litter } \\
\text { Saprotroph-Plant Pathogen-Soil } \\
\text { Saprotroph-Wood Saprotroph }\end{array}$ & Microfungus & Soft rot & $\begin{array}{l}\text { Lagarde et al. (2018); } \\
\quad \text { Kim et al. (2019) }\end{array}$ \\
\hline $\begin{array}{l}\text { SH216250.07F } \\
\text { U_EF679363_r } \\
\text { efs }\end{array}$ & & 4.16 & 7.31 & Cladosporium & $\begin{array}{l}\text { Animal Pathogen-Endophyte- } \\
\text { Lichen Parasite-Plant } \\
\text { Pathogen-Wood Saprotroph }\end{array}$ & Microfungus & - & $\begin{array}{l}\text { Chen et al. (2018); } \\
\text { Lagarde et al. (2018) }\end{array}$ \\
\hline $\begin{array}{l}\text { New.Reference } \\
\text { OTU140 }\end{array}$ & & 2.75 & 12.7 & Aureobasidium & $\begin{array}{l}\text { Endophyte-Epiphyte-Plant } \\
\text { Pathogen-Undefined } \\
\text { Saprotroph }\end{array}$ & $\begin{array}{l}\text { Facultative } \\
\text { Yeast }\end{array}$ & - & $\begin{array}{c}\text { Rathnayake et al. } \\
(2018)\end{array}$ \\
\hline $\begin{array}{l}\text { New.CleanUp. } \\
\text { ReferenceOTU } \\
2031\end{array}$ & & 1.00 & 0.00 & Phoma & $\begin{array}{l}\text { Endophyte-Dung Saprotroph- } \\
\text { Lichen Parasite-Litter } \\
\text { Saprotroph-Plant Pathogen-Soil } \\
\text { Saprotroph-Wood Saprotroph }\end{array}$ & Microfungus & Soft rot & $\begin{array}{l}\text { Lagarde et al. (2018); } \\
\quad \text { Kim et al. (2019) }\end{array}$ \\
\hline $\begin{array}{l}\text { New.CleanUp. } \\
\text { ReferenceOTU } \\
4820\end{array}$ & & 0.93 & 2.56 & Alternaria & $\begin{array}{l}\text { Animal Pathogen-Endophyte- } \\
\text { Plant Pathogen-Wood } \\
\text { Saprotroph }\end{array}$ & Microfungus & Soft rot & Lincoln et al. (2018) \\
\hline $\begin{array}{l}\text { New.CleanUp. } \\
\text { ReferenceOTU } \\
11423\end{array}$ & & 0.15 & 0.00 & Acremonium & $\begin{array}{l}\text { Animal Pathogen-Endophyte- } \\
\text { Fungal Parasite-Plant } \\
\text { Pathogen-Wood Saprotroph }\end{array}$ & Microfungus & $\begin{array}{c}\text { Soft rot, } \\
\text { endophyte } \\
\text { pathogen, likely } \\
\text { opportunistic } \\
\text { human pathogen }\end{array}$ & $\begin{array}{l}\text { Selvakumar and } \\
\text { Panneerselvam } \\
\text { (2018) }\end{array}$ \\
\hline $\begin{array}{l}\text { New.CleanUp. } \\
\text { ReferenceOTU } \\
\quad 8326\end{array}$ & 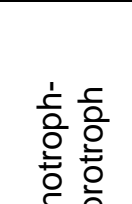 & 0.77 & 0.00 & Mycosphaerellaceae & $\begin{array}{l}\text { Plant Pathogen-Undefined } \\
\text { Saprotroph }\end{array}$ & Microfungus & $\begin{array}{l}\text { Biotrophic, } \\
\text { necrotrophic or } \\
\text { saprobic on } \\
\text { various plant } \\
\text { tissues }\end{array}$ & Santini et al. (2018) \\
\hline $\begin{array}{l}\text { New.CleanUp. } \\
\text { ReferenceOTU } \\
5116\end{array}$ & $\begin{array}{l}\bar{t} \text { ते } \\
0 \\
0\end{array}$ & 0.10 & 0.05 & Malassezia & $\begin{array}{l}\text { Animal Pathogen-Undefined } \\
\text { Saprotroph }\end{array}$ & $\begin{array}{l}\text { Facultative } \\
\text { Yeast }\end{array}$ & Skin diseases & Theelen et al. (2018) \\
\hline
\end{tabular}


bioresources.com

\begin{tabular}{|c|c|c|c|c|c|c|c|c|}
\hline $\begin{array}{l}\text { New.CleanUp. } \\
\text { ReferenceOTU } \\
\quad 900\end{array}$ & & 0.02 & 0.42 & Leptosphaeriaceae & $\begin{array}{c}\text { Plant Pathogen-Wood } \\
\text { Saprotroph }\end{array}$ & Microfungus & $\begin{array}{c}\text { Saprobic or } \\
\text { weakly } \\
\text { necrotrophic on } \\
\text { stems or leaves }\end{array}$ & Chen et al. (2018) \\
\hline $\begin{array}{l}\text { New.CleanUp. } \\
\text { ReferenceOTU } \\
14202\end{array}$ & & 0.02 & 0.46 & Didymella & $\begin{array}{c}\text { Animal Pathogen-Plant } \\
\text { Pathogen-Undefined } \\
\text { Saprotroph }\end{array}$ & Microfungus & - & Salehi et al. (2019) \\
\hline $\begin{array}{l}\text { New.CleanUp. } \\
\text { ReferenceOTU } \\
609\end{array}$ & & 0.00 & 0.20 & Sporobolomyces & $\begin{array}{c}\text { Fungal Parasite-Litter } \\
\text { Saprotroph }\end{array}$ & Yeast & - & Nagai (2018) \\
\hline $\begin{array}{l}\text { New.CleanUp. } \\
\text { ReferenceOTU } \\
\quad 5551\end{array}$ & \multirow{3}{*}{$\begin{array}{l}\text { 등 } \\
\text { 을 } \\
\text { 음 } \\
\text { 둠 } \\
0\end{array}$} & 0.50 & 0.07 & Leptosphaeria & Plant Pathogen & Probable & - & Fudal et al. (2018) \\
\hline $\begin{array}{l}\text { New.CleanUp. } \\
\text { ReferenceOTU } \\
11223\end{array}$ & & 0.19 & 0.00 & Exobasidium & Plant Pathogen & - & - & $\begin{array}{c}\text { Karakaya and Dikilitas } \\
\text { (2018) }\end{array}$ \\
\hline $\begin{array}{l}\text { SH194775.07F } \\
\text { U_AF444292_r } \\
\text { efs }\end{array}$ & & 0.02 & 1.82 & Rhodotorula & $\begin{array}{c}\text { Animal Endosymbiont-Animal } \\
\text { Pathogen-Endophyte-Plant } \\
\text { Pathogen-Undefined } \\
\text { Saprotroph }\end{array}$ & Yeast & $\begin{array}{c}\text { Opportunistic } \\
\text { human pathogen }\end{array}$ & Sen et al. (2019) \\
\hline
\end{tabular}


a) 120

a)

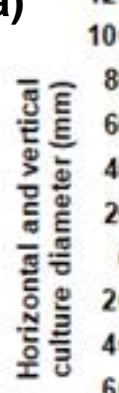

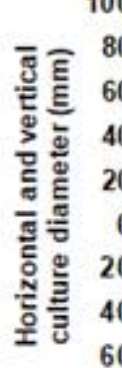

80

100
口G166/18

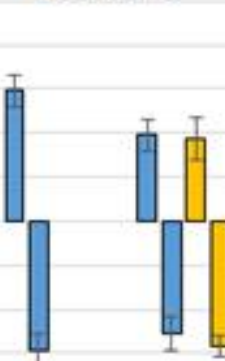

C

AP
口Antagonism treatment

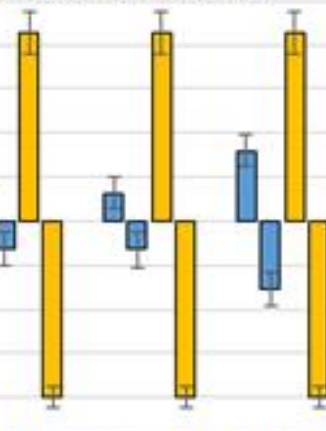

G79/11 AP.G79/11 MET
Treatment

b) 120

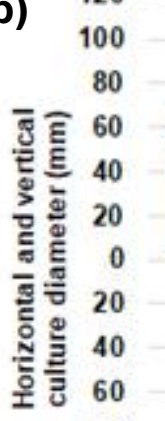
80 100
DG168/18

口Antagonism tre atment

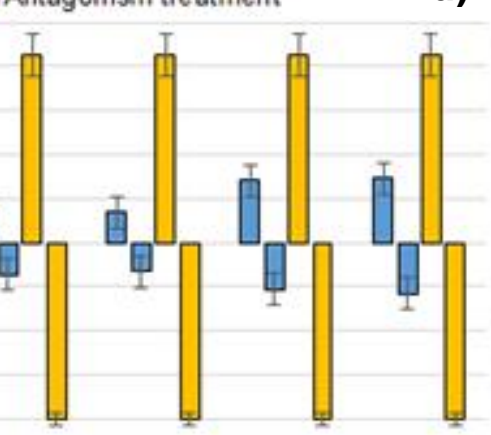

G79/11 AP.G79/11 MET

Treatment c)

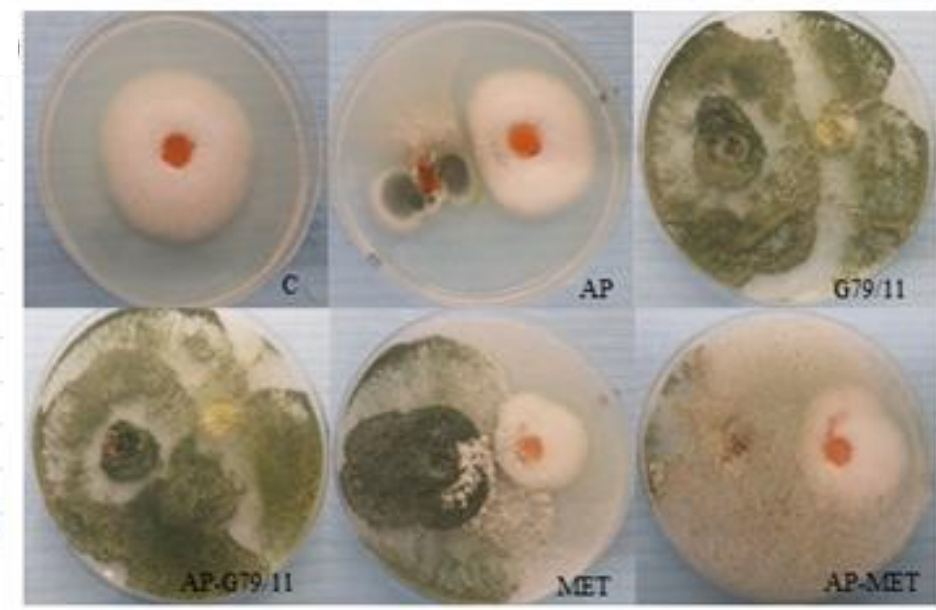

d)

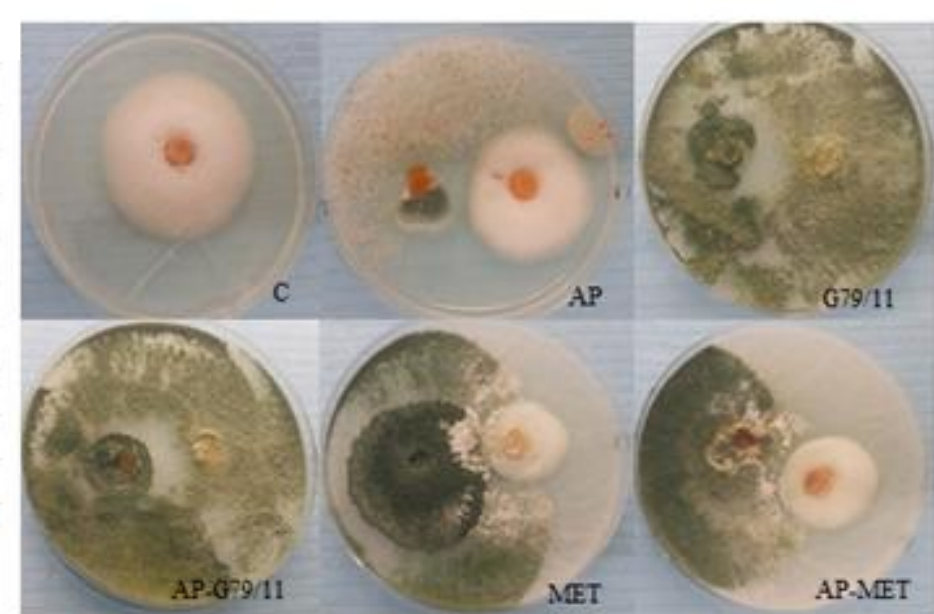

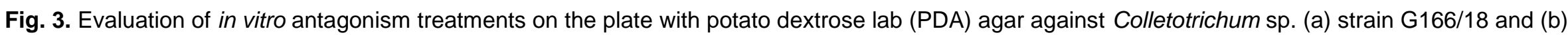
strain G168/18, with photographic documentation (c) and (d), respectively. Explanations: $C$ is pathogen growth control; antagonism treatments are as follows: AP, apple pomace; G79/11, Trichoderma atroviride G79/11; AP-G79/11, apple pomace inoculated with Trichoderma atroviride G79/11; MET, metaferm biopreparation; AP-MET, apple pomace with addition of metaferm; $\mathrm{n}=3$, the error bars represent standard error. 

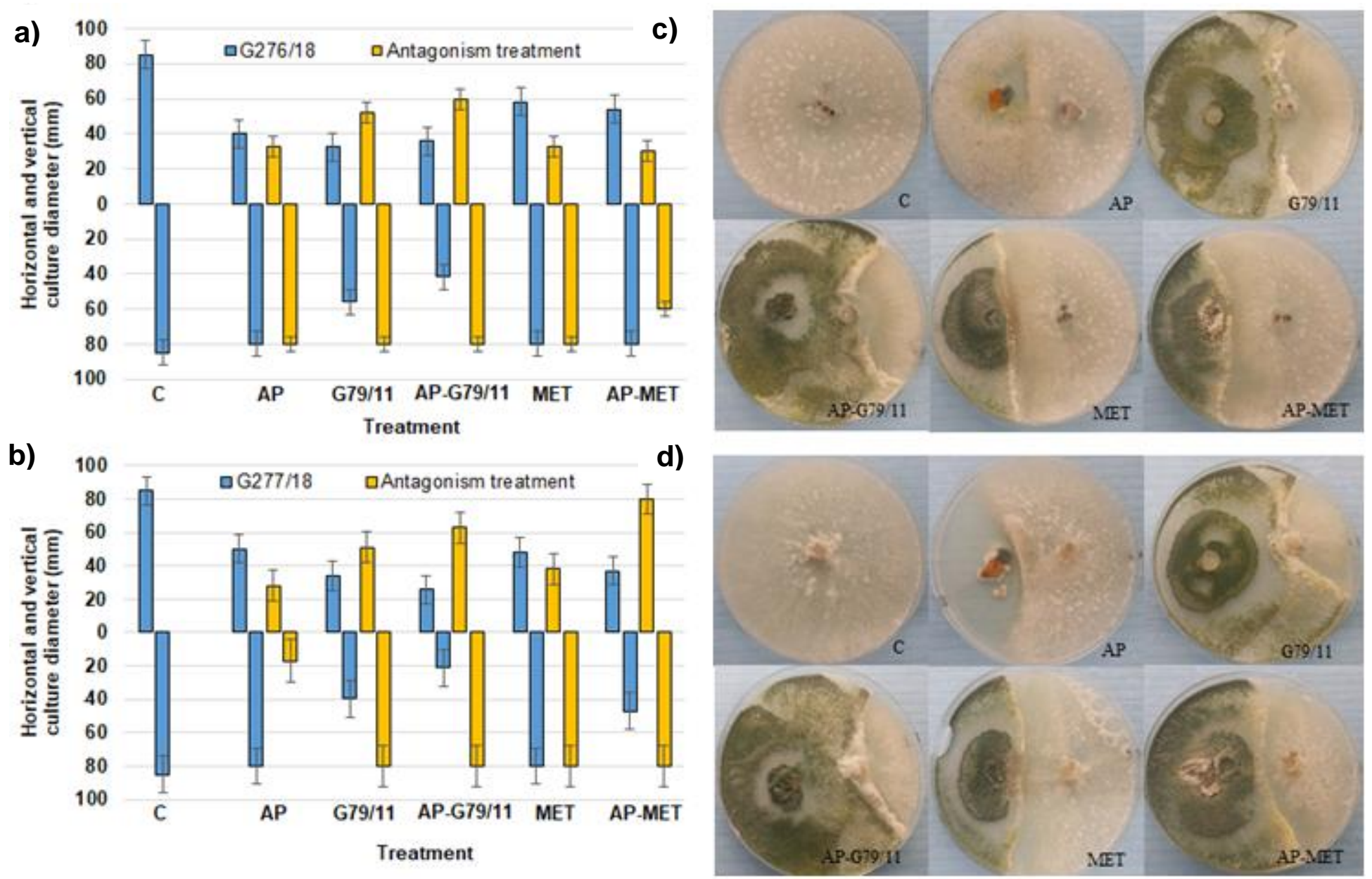

Fig. 4. Evaluation of in vitro antagonism treatments on the plate with PDA against Botrytis sp. (a) strain G276/18 and (b) strain G277/18, with photographic documentation (c) and (d), respectively. For explanations please see Fig. 3 caption. 

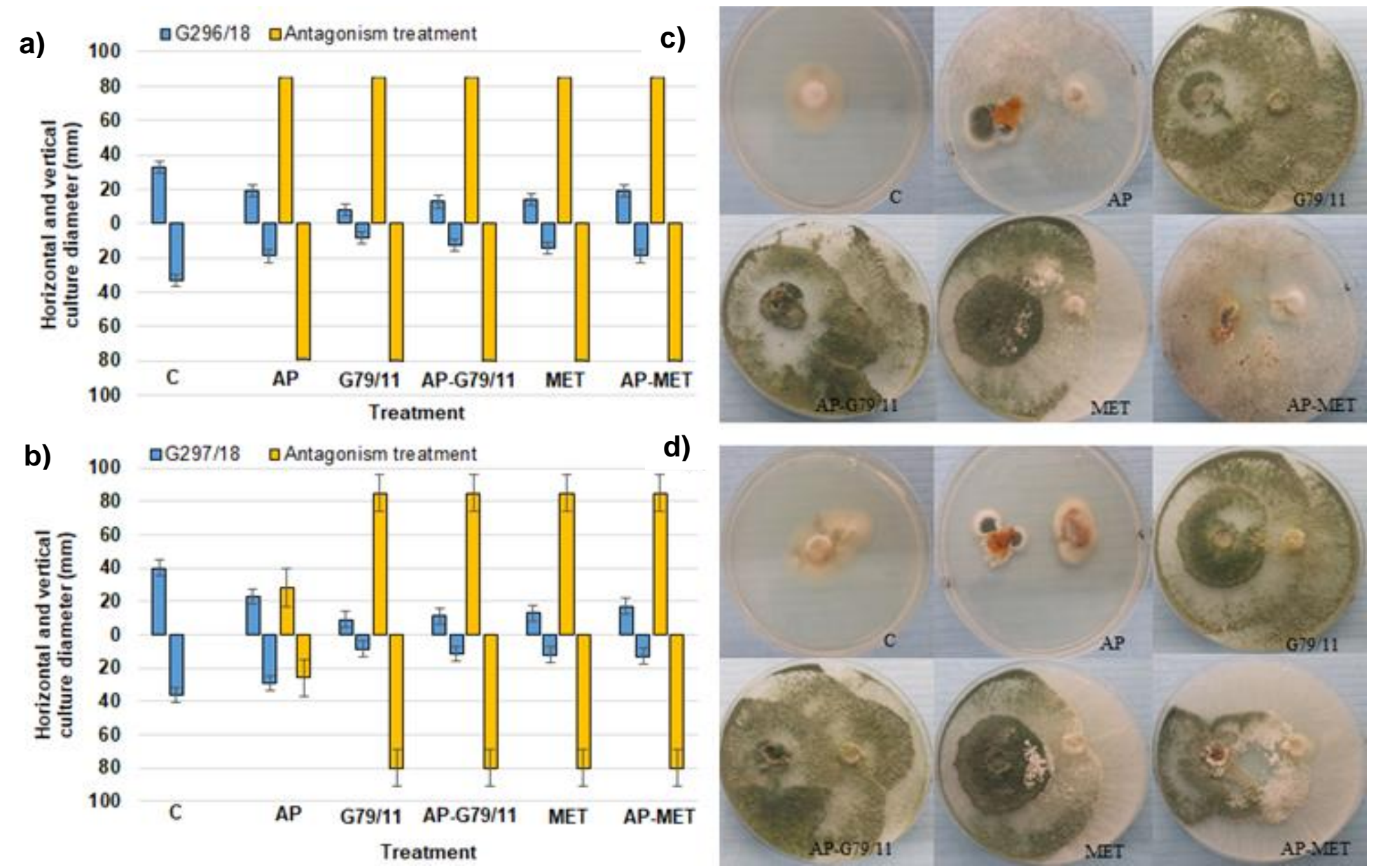

Fig. 5. Evaluation of in vitro antagonism treatments on the plate with PDA against Verticillium sp. (a) strain G296/18 and (b) strain G297/18, with photographic documentation (c) and (d), respectively. For explanations please see Fig. 3 caption. 
a)

100

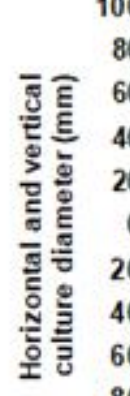

80

100

$\square$ G368/18 aAntagonism treatment

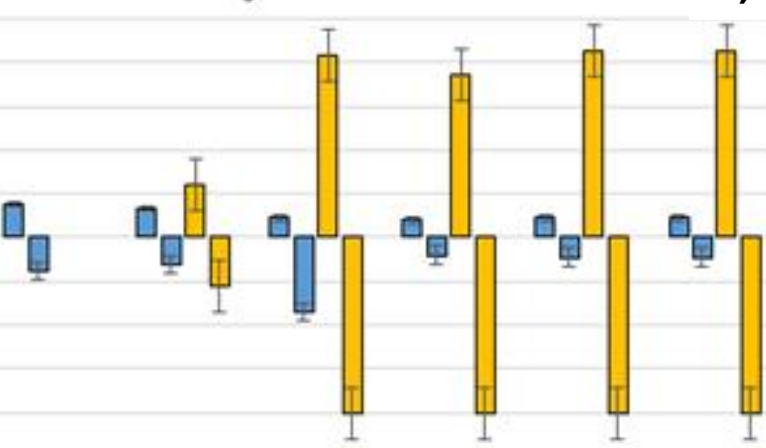

C

c)

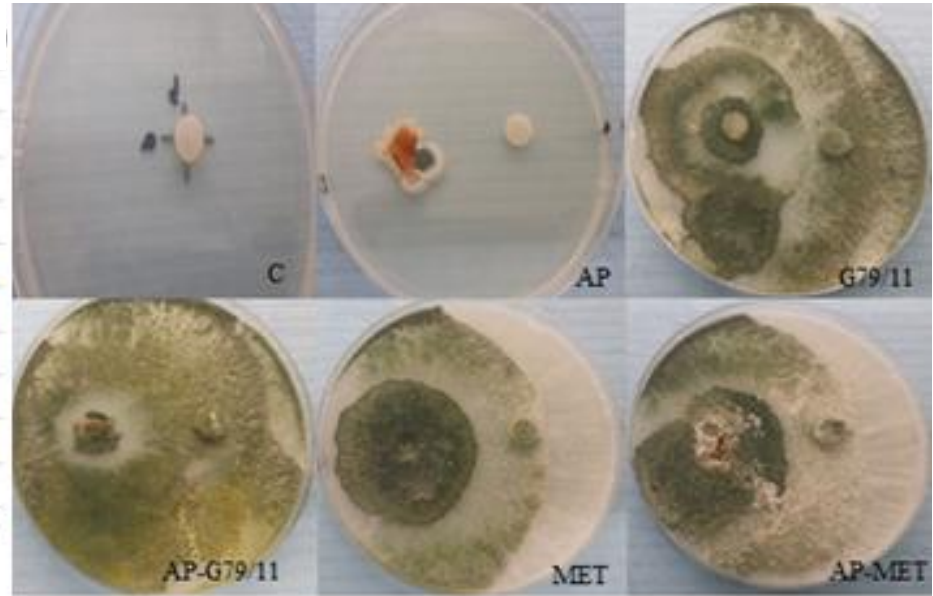

d)

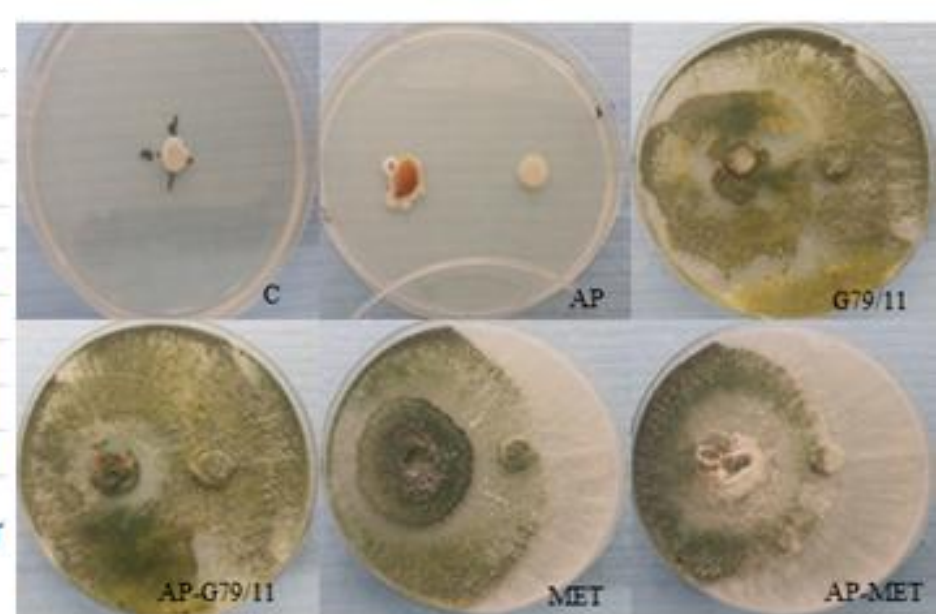

b)

口G373/18 aAntagonism treatment

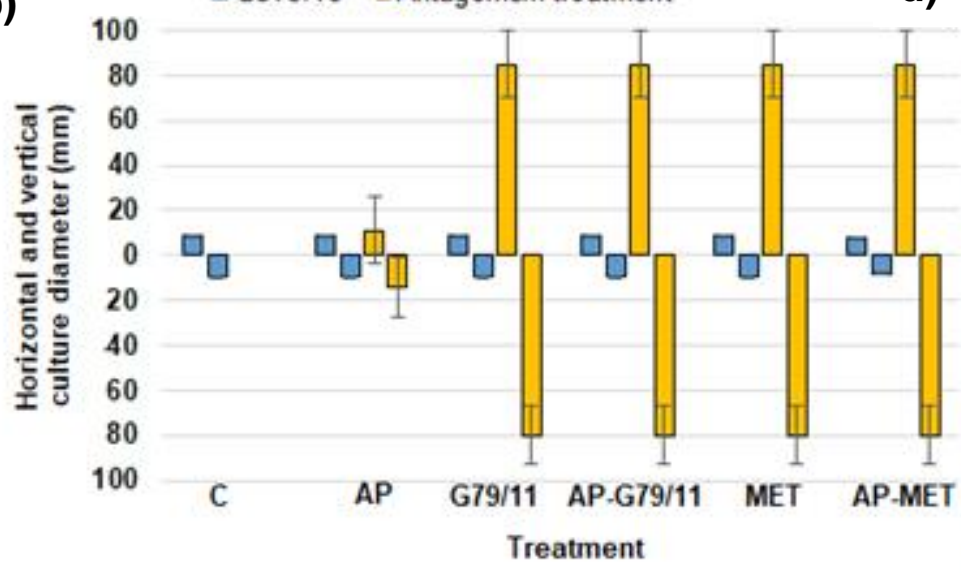

Fig. 6. Evaluation of in vitro antagonism treatments on the plate with PDA against Phytophthora sp. (a) strain G368/18 and (b) strain G373/18, with photographic documentation (c) and (d), respectively. For explanations, please see Fig. 3 caption. 
Figures $7 \mathrm{a}$ and $7 \mathrm{~b}$ show the absorbance normalized values and the ratio between the values of substrate use (respiration) and growth patterns (biomass production) by the fungal community, for particular groups of substrates on the FF plate, for AP and OAP, respectively. For AP (Fig. 7a), the ratio values were varied, ranging from 0.9 in the polyols group to 1.86 in aliphatic organic acids. Polyols generated the largest functional response (both in terms of growth and substrate use). More modest responses were generated by the following substances (in descending order): oligosaccharides, glucosides, hexoses, TCAcycle intermediates, L-amino acids, peptides, pentoses, biogenic and heterocyclic amines, hexosamines, and heptose. Other groups, such as polysaccharides, sugar acids, and aliphatic groups, produced the smallest functional response. In OAP (Fig. 7b), the ratio values were stable and ranged from 1.0 to 1.8 for most of the substrate groups, and to 6.4 for pentoses. The functional responses were as follows (from the highest to the lowest): polyols, heptoses, oligosaccharides, polysaccharides, TCA-cycle intermediates, biogenic and heterocyclic amines, glucosides, others group, aliphatic organic acids, L-amino acids, sugar acids, hexosamines, pentoses, hexoses, and peptides.

\section{Apple Pomace Taxonomic Composition and Function}

The differences in the taxonomic compositions of fungal communities in apple pomace from conventionally grown apples and organic apple pomace were revealed. Abdelfattah et al. (2016) also found different population patterns and structures between organic and conventional apples. The findings of this study were in agreement with these results. Several unique taxa were exclusively detected in organic apples, suggesting that agricultural management practices may have been a contributing factor in determining the taxa present in the plant material.

Previous studies indicated that apple surfaces teem with a wide variety of microorganisms, mainly fungi that are closely associated with postharvest deterioration in the fruit (Shen et al. 2018). In particular, such studies reported an increased level of Penicillium sp., Aspergillus sp., Mucor sp., and Botrytis sp. during apple storage; however, in the present study, none of the representatives of this genus were found in apple waste. Additionally, this study found the presence of Acremonium sp. representatives in apple pomace and organic apple pomace, but Shen et al. (2018) suggested that their proliferation is uncommon in the fungal communities of apple fruits during storage. It was previously stated that fruit surfaces also contain numerous unidentified fungi (Graça et al. 2015). The same results were demonstrated in this research. However, the present results also importantly contribute new knowledge concerning the fungal community composition in apple pomace, namely, the high-throughput sequencing technology approach.

Nonetheless, the ecological roles of the already identified barcode entries play a negative role as both a potential plant or animal pathogen, and/or a positive role as a saprotroph or fungal parasite, or/and endophyte/epiphyte. Therefore, its agricultural application may reveal some positive aspects by supplying the soil with an additional, reasonable amount of exogenous organic matter, as well as with nitrogen, phosphorus, and potassium. Apple pomace also carries a great number of fungal saprotrophs, and thereby ensures the circulation of organic matter. In contrast, the prospect of applying apple pomace in agricultural purposes may also pose disadvantages because many of its fungal representatives are phytopathogens. Previously, this problem was identified by Oszust et al. (2018b), who found the fungal pathogen Petriella setifera in industrial compost that consisted of sewage sludge from wastewater treatment, sawdust and biodegradable waste from gardens and from parks, soil, medicinal plants extracts, and lime sludge. 

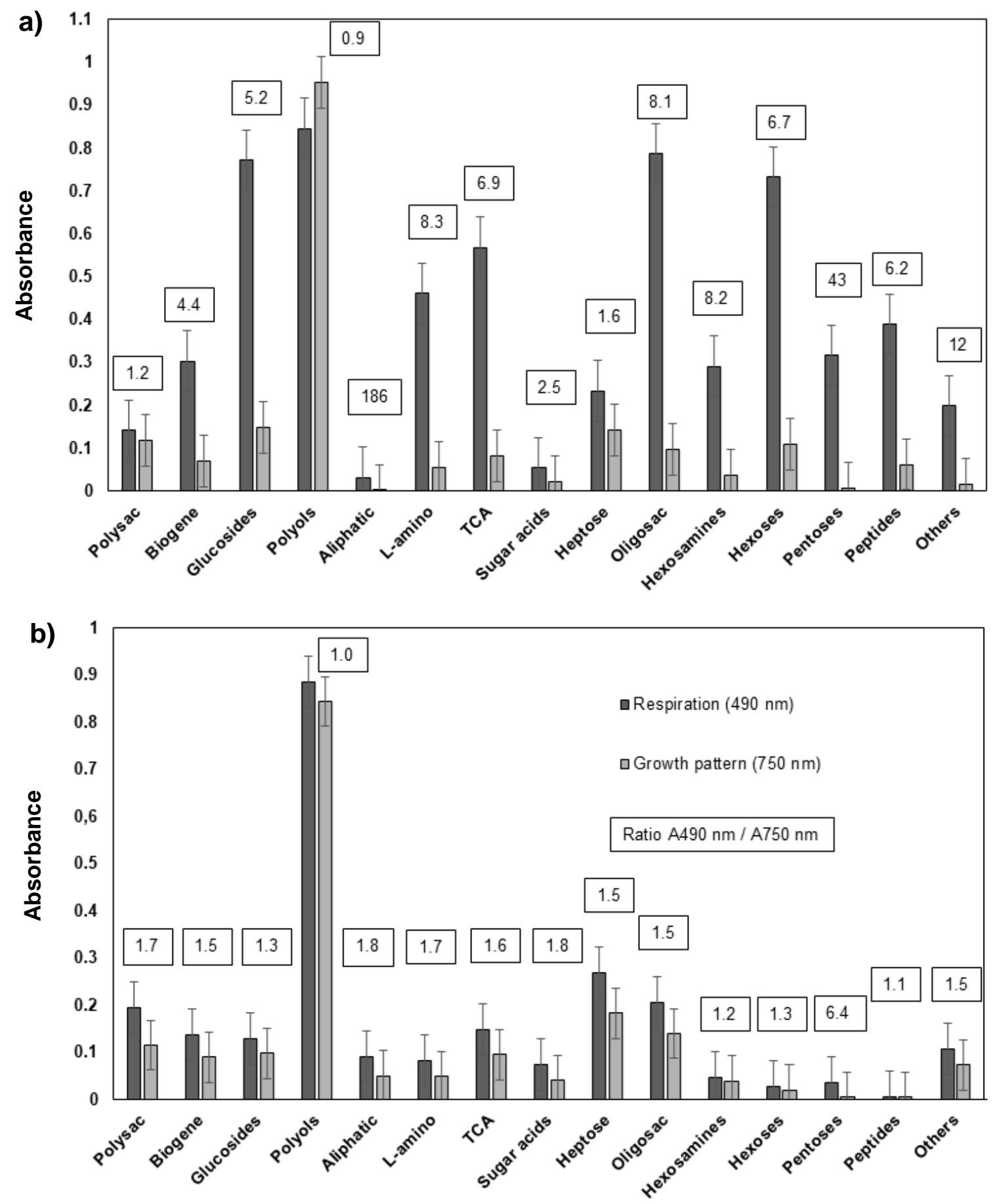

Group of substrates

Fig. 7. The absorbance normalized values of substrates use and growth pattern fungal community of a) AP and b) OAP based on FF Biolog® Plate. The ratio between values of substrate use (respiration, OD $490 \mathrm{~nm}$ ) and growth pattern (biomass/turbidity production, OD 750 $\mathrm{nm}$ ) for each particular group of substrates is shown in frames. Explanations: Polysac, polysaccharides; Biogene, biogene, and heterocyclic amines; Aliphatic, aliphatic organic acids; Lamino, L-amino acids; Oligosac, oligosaccharides; $n=3$; the error bars represent standard error. 
In many orchards, the shredded branches resulting from pruning trees or raspberry bushes are left in inter-row spaces and under trees. This waste wood containing lignin is persistent in nature. Apple pomace may be used to stimulate the growth of white-rot fungi in soil (Cea et al. 2010), which is another benefit of apple pomace field application. However, because fresh apple pomace is an acidic substrate with a considerable buffering capacity - attributable to malic acid and its salts (Hang and Walter 1989) - the appropriate dose of apple pomace should be calculated and adjusted to the $\mathrm{pH}$ value of the target soil.

In the research of Pinzari et al. (2016) and Pinzari et al. (2017), when comparing the ratios obtained for the two species of fungi (pure isolates), for example, Stachybotrys chartarum and Minimedusa polyspora, evidence was found that the two organisms have differing behaviour in the presence of different groups of substrates. The same was revealed in the present experiments concerning fungal communities of apple pomace. This finding is probably related to the manner of apples production (conventional or organic farming) and the apple variety composition, which regulates its fungal community functionality. Additionally, Arrigoni et al. (2018) suggests that tissue age and plant genotype affect the microbiota of apple and pear bark.

The greatest diversity of ratio values for a particular group of substrates in apple pomace compared with organic apple pomace (Fig. 3) suggests that the apple pomace fungal community has the ability to respond to a larger variety of substrates. However, as Pinzari et al. (2017) theoretically describes, a lower ratio results in a more efficient metabolism. That criterion was met for organic apple pomace. A low ratio, compared with a high one, indicates that a relatively large fungal biomass developed without consuming too much substrate. The opposite situation occurred with regard to apple pomace: a small biomass (low OD values at $750 \mathrm{~nm}$ ) yielded high respiration rates (high OD values at 490 $\mathrm{nm}$ ), indicating a stressful metabolic situation.

According to this interpretation, which, in some cases, may be clearly and definitely applied, fungi in the apple pomace obtained by conventional farming methods appeared to be more compatible with polyols and polysaccharides. The fungi in the organic apple pomace showed high efficiency when growing on most of the tested substrates, and especially on polyols (excluding pentoses). That apple pomace from conventional and organic farming carries a fungal load with high tendency to grow on substrates, such as polyols, is useful when considering its potential agricultural and horticultural applications. It is theorized that adding apple pomace to soil may improve the processing of bioresourcebased polyols, including the lignin or soy oil-derived polyols discussed above (Luo et al. 2018).

\section{Trichoderma atroviride G79/11 Formulation on Apple Pomace}

Trichoderma atroviride G79/11 demonstrated cellulolytic activity (Oszust et al. 2017b). Moreover, the study indicated that this fungus also developed well on apple pomace and assumed an antagonistic mode against Colletotrichum sp., Botrytis sp., Verticillium sp., and Phytophthora sp. isolates. Therefore, apple pomace with T. atroviride G79/11 formulation could be applied in the field as a vehicle to suppress plant pathogens. Many other scientists have also examined the production of antimicrobial compounds by studying the Trichoderma sp., and have discovered that these fungi have the ability to produce toxic metabolites used by the fungi to inhibit the growth of other competitors in the ecological niche (pathogenic fungi) (Berg et al. 2004). Due to their ability to produce chitinase, many representatives of fungi belonging to the Trichoderma sp. are able to degrade pathogen cell walls (Larkin 2016). 
The formulations proposed in this paper do not require the addition of nitrogen, or the adjustment of the $\mathrm{pH}$, as Kalidas (1999) describes is necessary for the growth of antagonistic microorganisms in solid waste such as apple, strawberry, and/or cranberry pomace. Apple pomace, with the presented chemical composition, is primarily indicative of the content of cellulose ( $c a 8.8 \mathrm{~g} / 100 \mathrm{~g} \mathrm{d.m}$.) (Szymańska-Chargot et al. 2019), which is a suitable substrate by which to develop a strain with the high cellulolytic activity of Trichoderma atroviride G79/11.

The tested multi-enzymatic biopreparation metaferm, based on the concentrated submerged culture in soy flour-cellulose-lactose medium of Trichoderma atroviride G79/11, produces conidial spores that are virile enough to initiate growth on apple pomace. It seems that long-term metaferm storage does not negatively influence Trichoderma atroviride G79/11 spores in their ability to thrive and demonstrate antagonistic activity. It is also possible that the inherent pathogens of apple pomace, described above, may be suppressed by the spread and prospering of Trichoderma atroviride G79/11.

\section{CONCLUSIONS}

1. The most abundant taxonomic genus identified in both AP and OAP were Aureobasidium, Cladosporium, and Alternaria, classified into the pathotrophsaprotroph-symbiotroph groups.

2. Unique taxa were exclusively detected in organic apples, suggesting that agricultural management practices may have been a contributing factor in determining the taxa present. Phoma, Acremonium, Mycosphaerellaceae, and Exobasidium were mainly found in AP. Leptosphaeriaceae, Didymella, Sporobolomyces, and Rhodotorula were found only in OAP.

3. The ecological roles identified for fungi are complex, as they may play a negative role as plant or animal pathogens, and they may simultaneously play a positive role as a saprotroph or fungal parasite, endophyte or epiphyte.

4. The indigenous fungal representatives of apple pomace may be introduced into the soil ecosystem, and they may undertake ecological roles influencing plant health as symbionts, decomposers, or pathogens.

5. The Trichoderma atroviride G79/11 strain has an antagonistic potential against Colletotrichum sp., Botrytis sp., Verticillium sp., and Phytophthora sp., and develops well on apple pomace. Therefore, Trichoderma atroviride G79/11 may be applied to the soil. It has been proven that both formulations of AP with G79/11 spores or AP with metaferm biopreparation act effectively against fungal pathogen.

\section{ACKNOWLEDGMENTS}

The study was financed by The National Centre for Research and Development in frame of project BIOSTRATEG, contract no. BIOSTRATEG3/344433/16/NCBR/2018.

Karolina Oszust designed the study, collected the data, interpreted the results, and wrote the manuscript draft. Magdalena Frąc provided ideas, designed the study, 
participated in the interpretation of results, performed reviews, and made corrections of the manuscript. Both authors read and approved the final manuscript.

\section{REFERENCES CITED}

Abdelfattah, A., Wisniewski, M., Droby, S., and Schena, L. (2016). "Spatial and compositional variation in the fungal communities of organic and conventionally grown apple fruit at the consumer point-of-purchase," Horticultural Research 3(1), Article Number 16047. DOI: 10.1038/hortres.2016.47

Arrigoni, E., Antonielli, L., Pindo, M., Pertot, I., and Perazzolli, M. (2018). "Tissue age and plant genotype affect the microbiota of apple and pear bark," Microbiological Research 211, 57-68. DOI: 10.1016/j.micres.2018.04.002

Caporaso, J. G., Kuczynski, J., Stombaugh, J., Bittinger, K., Bushman, F. D., Costello, E. K., Fierer, N., Peña, A. G., Goodrich, J. K., Gordon, J. I., et al. (2010). “QIIME allows analysis of high-throughput community sequencing data," Nature Methods 7(5), 335-336. DOI: 10.1038/nmeth.f.303

Chen, W., Hambleton, S., Seifert, K. A., Carisse, O., Diarra, M. S., Peters, R. D., Lowe, C., Chapados, J. T., and Lévesque, C. A. (2018). "Assessing performance of spore samplers in monitoring aeromycobiota and fungal plant pathogen diversity in Canada," Applied and Environmental Microbiology 84(9), e02601-02617. DOI: 10.1128/aem.02601-17

DeSantis, Jr., T. Z., Hugenholtz, P., Keller, K., Brodie, E. L., Larsen, N., Piceno, Y. M., Phan, R., and Andersen, G. L. (2006a). "NAST: A multiple sequence alignment server for comparative analysis of 16S rRNA genes," Nucleic Acids Research 1(34), W394-W399.

DeSantis, Jr., T. Z., Hugenholtz, P., Larsen, N., Rojas, M., Brodie, E. L., Keller, K., Huber, T., Dalevi, D., Hu, P., and Andersen, G. L. (2006b). "Greengenes, a chimerachecked 16S rRNA gene database and workbench compatible with ARB," Applied and Environmental Microbiology 72(7), 5069-5072. DOI: 10.1128/AEM.03006-05

Dolan, A., MacFarlane, S., and Jennings, S. N. (2018). "Pathogens in raspberry and other Rubus spp.," in: Raspberry: Breeding, Challenges and Advances, J. Graham and R. Brennan (eds.), Springer International Publishing, Cham, Switzerland, pp. 41-61. DOI: 10.1007/978-3-319-99031-6_4

Fan, R., Cockerton, H. M., Armitage, A. D., Bates, H., Cascant-Lopez, E., Antanaviciute, L., Xu, X., Hu, X., and Harrison, R. J. (2018). "Vegetative compatibility groups partition variation in the virulence of Verticillium dahliae on strawberry," PLOS ONE 13(2), e0191824. DOI: 10.1371/journal.pone.0191824

Forcelini, B. B., Rebello, C. S., Wang, N. Y., and Peres, N. A. (2018). "Fitness, competitive ability, and mutation stability of isolates of Colletotrichum acutatum from strawberry resistant to QoI Fungicides," Phytopathology 108(4), 462-468. DOI: 10.1094/PHYTO-09-17-0296-R

Frac, M., Oszust, K., Lipiec, J., Jezierska-Tys, S., and Nwaichi, E. O. (2014). "Soil microbial functional and fungal diversity as influenced by municipal sewage sludge accumulation," International Journal of Environmental Research and Public Health 11(9), 8891-8908. DOI: 10.3390/ijerph110908891 
Fudal, I., Balesdent, M. H., and Rouxel, T. (2018). "Effector biology in fungal pathogens of nonmodel crop plants," Trends in Plant Science 23(9), 753-755. DOI: 10.1016/j.tplants.2018.07.002

Graça, A., Santo, D., Esteves, E., Nunes, C., Abadias, M., and Quintas, C. (2015). "Evaluation of microbial quality and yeast diversity in fresh-cut apple," Food Microbiology 51, 179-185. DOI: 10.1016/j.fm.2015.06.003

Hang, Y. D., and Walter, R. H. (1989). "Treatment and utilization of apple-processing wastes," in: Processed Apple Products, D. L. Downing (ed.), Springer US, New York, NY, pp. 365-377. DOI: 10.1007/978-1-4684-8225-6_17

Jeszka-Skowron, M., Oszust, K., Zgoła-Grześkowiak, A., and Frąc, M. (2018). "Quality assessment of goji fruits, cranberries, and raisins using selected markers," European Food Research and Technology 244(12), 2159-2168. DOI: 10.1007/s00217-0183125-1

Kalidas, S. (1999). "Fruit pomace compositions and uses thereof," U.S. Patent. No. 5882641.

Karakaya, A., and Dikilitas, M. (2018). "Biochemical, physiological and molecular defence mechanisms of tea plants against pathogenic agents under changing climate conditions," in: Stress Physiology of Tea in the Face of Climate Change, W.-Y. Han, X. Li, and G. J. Ahammed (eds.), Springer Singapore, Singapore, pp. 241-268. DOI: 10.1007/978-981-13-2140-5_11

Kiełbasa, M. (2015). "Przyszłość sektora rolno - spożywczego w Polsce w odniesieniu do stanu obecnego [The future of the agri-food sector in Poland in relation to the current state]," Progress in Economic Sciences 2(2), 236-248. DOI: 10.14595/PES/02/016

Kim, J. W., Choi, H. G., Song, J. H., Kang, K. S., and Shim, S. H. (2019). "Bioactive secondary metabolites from an endophytic fungus Phoma sp. PF2 derived from Artemisia princeps Pamp.," The Journal of Antibiotics 72(3), 174-177. DOI: 10.1038/s41429-018-0131-2

Kozhar, O., and Peever, T. L. (2018). "How does Botrytis cinerea infect red raspberry?," Phytopathology 108(11), 1287-1298. DOI: 10.1094/PHYTO-01-18-0016-R

Lagarde, A., Jargeat, P., Roy, M., Girardot, M., Imbert, C., Millot, M., and Mambu, L. (2018). "Fungal communities associated with Evernia prunastri, Ramalina fastigiata and Pleurosticta acetabulum: Three epiphytic lichens potentially active against Candida biofilms," Microbiological Research 211, 1-12. DOI:

10.1016/j.micres.2018.03.006

Lincoln, J. E., Sanchez, J. P., Zumstein, K., and Gilchrist, D. G. (2018). "Plant and animal PR1 family members inhibit programmed cell death and suppress bacterial pathogens in plant tissues," Molecular Plant Pathology 19(9), 2111-2123. DOI: 10.1111/mpp.12685

Lipiński, A. J., Lipiński, S., and Kowalkowski, P. (2018). "Utilization of post-production waste from fruit processing for energetic purposes: Analysis of Polish potential and case study," Journal of Material Cycles Waste Management 20(3), 1878-1883. DOI: 10.1007/s10163-018-0729-2

Luo, X., Xiao, Y., Wu, Q., and Zeng, J. (2018). "Development of high-performance biodegradable rigid polyurethane foams using all bioresource-based polyols: Lignin and soy oil-derived polyols," International Journal of Biological Macromolecules 115, 786-791. DOI: 10.1016/j.ijbiomac.2018.04.126 
Mercy, S., Mubsira Banu, S., and Jenifer, I. (2014). "Application of different fruit peels formulations as a natural fertilizer for plant growth," International Journal of Scientific \& Technology Research 3(1), 300-307.

Mourtzinos, I., and Goula, A. (2019). "Polyphenols in agricultural byproducts and food waste," in: Polyphenols in Plants, R. R. Watson (ed.), Academic Press, New York, NY, pp. 23-44. DOI: 10.1016/B978-0-12-813768-0.00002-5

Nagai, T. (2018). "A novel, efficient, and ecologically relevant bioassay method using aquatic fungi and fungus-like organisms for fungicide ecological effect assessment," Environmenta Toxicology and Chemistry 37(7), 1980-1989. DOI: 10.1002/etc.4138

Nellist, C. F. (2018). "Disease resistance in polyploid strawberry," in: The Genomes of Rosaceous Berries and Their Wild Relatives, T. Hytönen, J. Graham, and R. Harrison (eds.), Springer International Publishing, Cham, Switzerland, pp. 79-94. DOI: 10.1007/978-3-319-76020-9_7

Nellist, C. F., Vickerstaff, R. J., Sobczyk, M. K., Marina-Montes, C., Brain, P., Wilson, F. M., Simpson, D. W., Whitehouse, A. B., and Harrison, R. J. (2018). "Quantitative trait loci controlling Phytophthora cactorum resistance in the cultivated octoploid strawberry (Fragaria x ananassa)," Horticultural Research 6(60), 1-14. DOI: $10.1101 / 249573$

Nguyen, N. H., Song, Z., Bates, S. T., Leho, T., Menke, J., Schillinge, J. S., and Kennedy, P. G. (2016). "FUNGuild: An open annotation tool for parsing fungal community datasets by ecological guild," Fungal Ecology 20, 241-248. DOI: 10.1016/j.funeco.2015.06.006

Oszust, K., and Frąc, M. (2018). "Evaluation of microbial community composition of dairy sewage sludge, corn silage, grass straw, and fruit waste biomass for potential use in biogas production or soil enrichment," BioResources 13(3), 5740-5764. DOI: 10.15376/biores.13.3.5740-5764

Oszust, K., Gryta, A., Ziemiński, K., Bilińska-Wielgus, N., Gałązka, R., and Frąc, M. (2018a). "Characterization of microbial functional and genetic diversity as a novel strategy of biowaste ecotoxicological evaluation," International Journal of Enviornmental Science and Technology 16(8), 4261-4274. DOI: 10.1007/s13762018-2066-3

Oszust, K., Panek, J., Pertile, G., Siczek, A., Oleszek, M., and Frąc, M. (2018b). "Metabolic and genetic properties of Petriella setifera precultured on waste," Frontiers in Microbiology 9(115), 1-10. DOI: 10.3389/fmicb.2018.00115

Oszust, K., Pawlik, A., Janusz, G., Ziemiński, K., Cyran, M., Siczek, A., Gryta, A., Bilińska-Wielgus, N., and Frąc, M. (2017a). "Characterization and influence of a multi-enzymatic biopreparation for biogas yield enhancement," BioResources 12(3), 6187-6206. DOI: 10.15376/biores.12.3.6187-6206

Oszust, K., Pawlik, A., Siczek, A., Janusz, G., Gryta, A., Bilińska-Wielgus, N., and Frąc, M. (2017b). "Efficient cellulases production by Trichoderma atroviride G79/11 in submerged culture based on soy flour-cellulose-lactose," BioResources 12(4), 84688489. DOI: 10.15376/biores.12.4.8468-8489

Pertile, G., Panek, J., Oszust, K., Siczek, A., and Frąc, M. (2018). "Intraspecific functional and genetic diversity of Petriella setifera," PeerJ 6, e4420. DOI: 10.7717/peerj.4420

Pinzari, F., Ceci, A., Abu-Samra, N., Canfora, L., Maggi, O., and Persiani, A. (2016). "Phenotype MicroArray system in the study of fungal functional diversity and 
catabolic versatility," Research in Microbiology 167(9-10), 710-722. DOI:

10.1016/j.resmic.2016.05.008

Pinzari, F., Maggi, O., Lunghini, D., Di Lonardo, P., and Persiani, A. M. (2017). “A simple method for measuring fungal metabolic quotient and comparing carbon use efficiency of different isolates: Application to Mediterranean leaf litter fungi," Plant Biosystems 151(2), 371-376. DOI: 10.1080/11263504.2017.1284166

Presterl, E., Diab-El Schahawi, M., Lusignani, L. S., Paula, H., and Reilly, J. S. (2018). "Medical mycology: Fungal infections," in: Basic Microbiology and Infection Control for Midwives, Springer International Publishing, Cham, Switzerland, pp. 155159. DOI: 10.1007/978-3-030-02026-2_17

Rathnayake, R. M. S. P., Savocchia, S., Schmidtke, L. M., and Steel, C. C. (2018). "Characterisation of Aureobasidium pullulans isolates from Vitis vinifera and potential biocontrol activity for the management of bitter rot of grapes," European Journal of Plant Pathology 151(3), 593-611. DOI: 10.1007/s10658-017-1397-0

Ray, R. C., and Ward, O. P. (2008). Microbial Biotechnology in Horticulure, Vol. 3, CRC Press, Boca Raton, FL, USA.

Röös, E., Mie, A., Wivstad, M., Salomon, E., Johansson, B., Gunnarsson, S., Wallenbeck, A., Hoffmann, R., Nilsson, U., Sundberg, C., and Watson, C. A. (2018). "Risks and opportunities of increasing yields in organic farming. A review," Agronomy for Sustainable Development 38(14), 1-14. DOI: 10.1007/s13593-0180489-3.

Salehi, M., Zibafar, E., Mahmoudi, S., Hashemi, S. J., Gatmiri, S. M., Gerami Shoar, M., Dehghan Manshadi, S. A., Jahanbin, B., Alizadeh, R., Hosseinpour, L., Ardi, P., and Daie Ghazvini, R. (2019). "First report of invasive pulmonary infection by Didymella microchlamydospora and successful treatment with voriconazole," Clinical Microbiology and Infection 25(3), 392-393. DOI: 10.1016/j.cmi.2018.10.018

Santini, A., Liebhold, A., Migliorini, D., and Woodward, S. (2018). "Tracing the role of human civilization in the globalization of plant pathogens," The ISME Journal 12(3), 647-652. DOI: 10.1038/s41396-017-0013-9

Schmidt, P. A., Bálint, M., Greshake, B., Bandow, C., Römbke, J., and Schmitt, I. (2013). "Illumina metabarcoding of a soil fungal community," Soil Biology and Biochemistry 65, 128-132. DOI: 10.1016/j.soilbio.2013.05.014

Selvakumar, V., and Panneerselvam, A. (2018). "Bioactive compounds from endophytic fungi," in: Fungi and Their Role in Sustainable Development: Current Perspectives, P. Gehlot and J. Singh (eds.), Springer, Singapore, pp. 699-717. DOI: 10.1007/978981-13-0393-7_36

Sen, D., Paul, K., Saha, C., Mukherjee, G., Nag, M., Ghosh, S., Das, A., Seal, A., and Tripathy, S. (2019). "A unique life-strategy of an endophytic yeast Rhodotorula mucilaginosa JGTA-S1 - a comparative genomics viewpoint," DNA Research 26(2), 131-146. DOI: 10.1093/dnares/dsy044

Shalini, R., and Gupta, D. K. (2010). "Utilization of pomace from apple processing industries: a review," Journal of Food Science and Technology 47(4), 365-371. DOI: 10.1007/s13197-010-0061-X

Shen, Y., Nie, J., Dong, Y., Kuang, L., Li, Y., and Zhang, J. (2018). “Compositional shifts in the surface fungal communities of apple fruits during cold storage," Postharvest Biology and Technology 144, 55-62. DOI:

10.1016/j.postharvbio.2018.05.005 
Szymańska-Chargot, M., Chylińska, M., Pieczywek, P. M., and Zdunek, A. (2019). "Tailored nanocellulose structure depending on the origin. Example of apple parenchyma and carrot root celluloses," Carbohydrate Polymers 210, 186-195. DOI: 10.1016/j.carbpol.2019.01.070

Theelen, B., Cafarchia, C., Gaitanis, G., Bassukas, I. D., Boekhout, T., and Dawson, T. L. (2018). "Corrigendum: Malassezia ecology, pathophysiology, and treatment," Medical Mycology 56(3), e2. DOI: 10.1093/mmy/myy046

Vilgalys, R. (1992). "Conserved primer sequences for PCR amplification of fungal rDNA," Vilgalys Mycology Lab - Duke University, (https://sites.duke.edu/vilgalyslab/rdna_primers_for_fungi), Accessed 1 Oct 2019.

Wang, X., Kristo, E., and LaPointe, G. (2019). "The effect of apple pomace on the texture, rheology and microstructure of set type yogurt," Food Hydrocolloids 91(1), 83-91. DOI: 10.1016/j.foodhyd.2019.01.004

Weber, R. W. S., and Hahn, M. (2019). "Grey mould disease of strawberry in northern Germany: Causal agents, fungicide resistance and management strategies," Applied Microbiology and Biotechnology 103(4), 1589-1597. DOI: 10.1007/s00253-01809590-1

Weiland, J. E., Benedict, C., Zasada, I. A., Scagel, C. R., Beck, B. R., Davis, A., Graham, K., Peetz, A., Martin, R. R., Dung, J. K. S., et al. (2017). "Late-summer disease symptoms in Western Washington red raspberry fields associated with co-occurrence of Phytophthora rubi, Verticillium dahliae, and Pratylenchus penetrans, but not raspberry bushy dwarf virus," Plant Disease 102(5), 938-947. DOI: 10.1094/PDIS08-17-1293-RE

Article submitted: October 10, 2019; Peer review completed: December 14, 2019;

Revised version received and accepted: December 16, 2019; Published: December 18, 2019.

DOI: 10.15376/biores.15.1.945-966 